\title{
Maksimal forventet hjertefrekvens
}

\author{
Ved belastningstest er det vanlig å ta utgangspunkt i formelen $220 \div$ alder for å vurdere om belastningsnivået \\ er tilstrekkelig. Formelen har svak dokumentasjon og underestimerer gjennomsnittlig maksimalpuls, mest \\ for de eldste. Selv mer korrekte formler er kun veiledende på grunn av stor spredning. Det er på tide \\ å parkere formelen $220 \div$ alder for godt.
}

Publisert først på nett 9.8. 2012

For at en belastningstest skal ha tilstrekkelig sensitivitet bør man oppnå adekvat intensitet $(1,2) .85 \%$ av maksimumsintensitet regnes vanligvis som tilstrekkelig. Imidlertid kjenner de færreste pasienter sin egen maksimalpuls. Maksimalpulsen faller nokså lineært med alder (3), og det har vært en utbredt praksis å estimere forventet maksimalpuls ut fra alder ved hjelp av en lineær regresjonsformel. Mest utbredt er formelen « $220 \div$ alder».

Det er tre spørsmål knyttet til bruk av denne:

- Hvor godt er formelen dokumentert vitenskapelig?

- Hvor godt beregner den gjennomsnittlig maksimalpuls?

- Hvor stor er spredningen i hver enkelt aldersgruppe, dvs. hvor godt predikerer aldersgjennomsnittet den individuelle maksimalpulsen?

\section{Ulike formler}

Formelen $\mathrm{HR}_{\text {maks }}=220 \div$ alder er ikke basert på én enkelt vitenskapelig studie, men på et gjennomsnitt av flere studier (4, 5), der faktisk ingen av dem var nær $220 \div$ alder. I en metaanalyse som ble validert i et uavhengig utvalg med over 500 friske individer kom man frem til regresjonsformelen: $\mathrm{HR}_{\text {maks }}=208 \div 0,7 \times$ alder (6).

I Helseundersøkelsen i Nord-Trøndelag (HUNT) testet vi maksimal hjertefrekvens hos 3320 friske personer $(7,8)$. Dette er den største enkeltundersøkelse av belastning og kondisjon til dags dato. Lineær regresjon ga alderssammenhengen $\mathrm{HR}_{\text {maks }}=211 \div 0,64 \times$ alder. Det var liten kjønnsforskjell og variabler som røyking, kroppsmasseindeks og maksimalt oksygenopptak hadde liten betydning. $77 \%$ oppnådde høyere puls enn forventet ut fra $220 \div$ alder $(61 \%$ av dem under 40 år, $81 \%$ av dem i alderen 40-60 år og $88 \%$ av dem over 60 år).

Like interessant var imidlertid spredningen i materialet på ca. $\pm 25 \mathrm{slag} \cdot \mathrm{min}^{-1}$ for alle aldersgrupper. Det vil si at selv et korrekt estimert aldersgjennomsnitt vil ha meget svak relevans for den enkelte pasient

Vi mener derfor at spørsmålene ovenfor kan besvares slik:

- Formelen $220 \div$ alder er ikke tilstrekkelig vitenskapelig dokumentert.

- Formelen vil underestimere forventet maksimalpuls hos voksne, mest hos de eldste.
- Spredningen i forventet maksimalpuls, selv med oppdaterte formler, er så stor, at maksimal hjertefrekvens ikke kan predikeres med akseptabel grad av presisjon hos enkeltpasienter

\section{Hva skal man anbefale?}

Når det gjelder kriterier for å avslutte en belastningstest hos pasienter, anbefales det $i$ europeiske retningslinjer først og fremst å anvende symptomer (herunder dyspné), deretter funn på EKG eller blodtrykk (9). Hos pasienter uten symptomer ved testing kan man ifølge retningslinjene vurdere å avslutte testen når maksimal forventet hjertefrekvens er oppnådd, med andre ord vesentlig mer enn $85 \%$ av maksimal intensitet. Dyspné hos en pasient uten tegn på hjerte- eller lungesykdom, er i seg selv et tegn på at man nærmer seg grensen for yteevnen. Under selve testen kan derfor dyspné brukes som et kriterium for å avslutte. Har pasienten nådd talegrensen,

\section{«Formelen $220 \div$ alder er ikke tilstrekkelig vitenskapelig doku- mentert»}

dvs. at hun eller han ikke lenger klarer å snakke i vanlige setninger, er ofte adekvat belastningsintensitet oppnådd. Hos de fleste tilsvarer talegrensen 15 på Borgs skala eller $85 \%$ av maksimal yteevne (10). Det å vurdere pasientens grad av dyspné, aktivt bruke Borgs skala hvor pasienten selv graderer anstrengelsen eller begge deler vil derfor sannsynligvis gi større sjanse for å oppnå an adekvat belastning enn forventet hjertefrekvens.

\section{Konklusjon}

Formelen $220 \div$ alder bør ikke brukes.

Nyere formler kan gi en mer korrekt prediksjon av gjennomsnittet for en aldersgruppe, men spredningen er imidlertid så stor at hver pasient bør vurderes individuelt, ut fra tegn til utmattelse.

\section{Asbjørn Støylen}

asbjorn.stoylen@ntnu.no

Bjarne Nes

Trine Karlsen
Asbjørn Støylen (f. 1956) er dr.med. og førsteamanuensis ved Institutt for sirkulasjon og bildediagnostikk, Norges teknisk-naturvitenskapelige universitet. Forskningsfelter er hovedsakelig kardiologisk ultralyd og hjertetrening. Forfatter har fylt ut ICMJE-skjemaet og oppgir følgende interessekonflikter: Instituttet har mottatt støttet fra Norges forskningsråd til dette forskningsprosjektet.

Bjarne M. Nes (f. 1981) er idrettsfysiolog og stipendiat ved K.G. Jebsen - Senter for hjertetrening.

Forfatter har fylt ut ICMJE-skjemaet og oppgir ingen interessekonflikter.

Trine Karlsen (f. 1972) er ph.d. og postdoktor ved K.G. Jebsen - Senter for hjertetrening. Forfatter har fylt ut ICMJE-skjemaet og oppgir ingen interessekonflikter.

Litteratur

1. Cumming GR. Yield of ischaemic exercise electro cardiograms in relation to exercise intensity in a normal population. Br Heart J 1972; 34: 919-23.

2. Gianrossi R, Detrano R, Mulvihill D et al. Exerciseinduced ST depression in the diagnosis of coronary artery disease. A meta-analysis. Circulation 1989; 80: 87-98

3. Robinson S. Experimental studies of physical fitness in relation to age. Arbeitsphysiologie 1938; 10: 25 .

4. Robergs RA, Landwehr R. The surprising history of the «HRmax $=220$-age» equation. JEP online 2002 5: $1-10$.

5. Fox SM 3rd, Naughton JP, Haskell WL. Physical activity and the prevention of coronary heart disease. Ann Clin Res 1971; 3: 404-32.

6. Tanaka H, Monahan KD, Seals DR. Age-predicted maximal heart rate revisited. J Am Coll Cardiol 2001; 37: 153-6.

7. Aspenes ST, Nilsen TI, Skaug EA et al. Peak oxygen uptake and cardiovascular risk factors in 4631 healthy women and men. Med Sci Sports Exerc 2011; 43: 1465-73.

8. Nes BM, Janszky I, Wisløff $U$ et al. Age-predicted maximal heart rate in healthy subjects: The HUNT Fitness Study. Scand J Med Sci Sports 2012; n/a.

9. Task force on the management of stable angina pectoris of the European Society of Cardiology. Guidelines on the management of stable angina pectoris. Eur Heart J. doi: 10.1093/eurheartj/ ehl002

10. Borg GA. Perceived exertion. Exerc Sport Sci Rev $1974 ; 2: 131-53$.

Mottatt 18.4. 2012, første revisjon innsendt 4.6. 2012, godkjent 28.6. 2012. Medisinsk redaktør Kristin Viste. 